\title{
Two years of measurements of atmospheric total gaseous mercury (TGM) at a remote site in Mt. Changbai area, Northeastern China
}

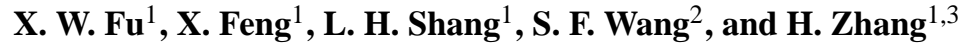 \\ ${ }^{1}$ State Key Laboratory of Environmental Geochemistry, Institute of Geochemistry, Chinese Academy of Sciences, Guiyang \\ 550002, China \\ ${ }^{2}$ Key Laboratory of Terrestrial Ecological Processes, Institute of Applied Ecology, Chinese Academy of Sciences, Shenyang, \\ China \\ ${ }^{3}$ Graduate University of the Chinese Academy of Sciences, Beijing 100049, China
}

Correspondence to: X. Feng (fengxinbin@vip.skleg.cn)

Received: 17 December 2011 - Published in Atmos. Chem. Phys. Discuss.: 7 February 2012

Revised: 23 April 2012 - Accepted: 23 April 2012 - Published: 11 May 2012

\begin{abstract}
Total gaseous mercury (TGM) was continuously monitored at a remote site (CBS) in Mt. Changbai area, Northeastern China from 24 October 2008 to 31 October 2010. The overall mean TGM concentration was $1.60 \pm 0.51 \mathrm{ng} \mathrm{m}^{-3}$, which is lower than those reported from remote sites in Eastern, Southwestern, and Western China, indicating a relatively lower regional anthropogenic mercury $(\mathrm{Hg})$ emission intensity in Northeastern China. Measurements at a site in the vicinity $(\sim 1.2 \mathrm{~km})$ of CBS station from August 2005 to July 2006 showed a significantly higher mean TGM concentration of $3.58 \pm 1.78 \mathrm{ng} \mathrm{m}^{-3}$. The divergent result was partially attributed to fluctuations in the relatively frequencies of surface winds during the two study periods and moreover an effect of local emission sources. The temporal variation of TGM at CBS was influenced by regional sources as well as long-range transported Hg. Regional sources frequently contributing to episodical high TGM concentrations were pin-pointed as a large iron mining district in Northern North Korea and two large power plants and urban areas to the southwest of the sampling site. Source areas in Beijing, Tianjin, southern Liaoning, Hebei, northwestern Shanxi, and northwestern Shandong were found to contribute to elevated TGM observations at CBS via longrange transport. Diurnal pattern of TGM at CBS was mainly controlled by regional sources, likely as well as intrusion of air masses from the free troposphere during summer season. There are no consistent seasonal pattern of TGM at CBS, and the monthly TGM variations showed links with the patterns of regional air movements and long-range transport.
\end{abstract}

\section{Introduction}

Mercury $(\mathrm{Hg})$ is a persistent, bio-accumulative and toxic chemical in the environment and has potential adverse effects on human health. $\mathrm{Hg}$ in the atmosphere, which is derived from both anthropogenic and natural emission sources, is generally operationally defined into three major forms, namely elemental gaseous mercury (GEM), gaseous oxidized mercury (GOM), and particulate bounded mercury (PBM), with the sum of GEM and GOM known as total gaseous mercury (TGM). Due to its high surface reactivity and water solubility, GOM and PBM are readily deposited on a local and/or regional scale. On the contrary, GEM, the most abundant form of $\mathrm{Hg}$ in the atmosphere $(>90 \%)$, has an atmospheric residence time of $\sim 0.5-2 \mathrm{yr}$ that is compatible with intra-hemispherical mixing (Schroeder and Munthe, 1998; Lindberg et al., 2007).

Recently, significant efforts have been donated to measure atmospheric TGM in remote areas on a global scale and to evaluate the effect of long-range transport, local and regional sources, as well as atmospheric physical and chemical processes of $\mathrm{Hg}$. The mean levels of TGM in remote areas of North America and Europe have been reported in the range of 1.3-1.7 $\mathrm{ng} \mathrm{m}^{-3}$ (e.g. Lee et al., 1998; Kellerhals et al., 2003; Poissant et al., 2005; Kock et al., 2005; Choi et al., 2008; Mao et al., 2008; Engle et al., 2010), and for the southern hemisphere in the range of $0.9-1.3 \mathrm{ng} \mathrm{m}^{-3}$ (Temme et al., 2003; Slemr et al., 2008; Brunke et al., 2010). Nevertheless, observations of TGM in many relatively remote areas of

Published by Copernicus Publications on behalf of the European Geosciences Union. 


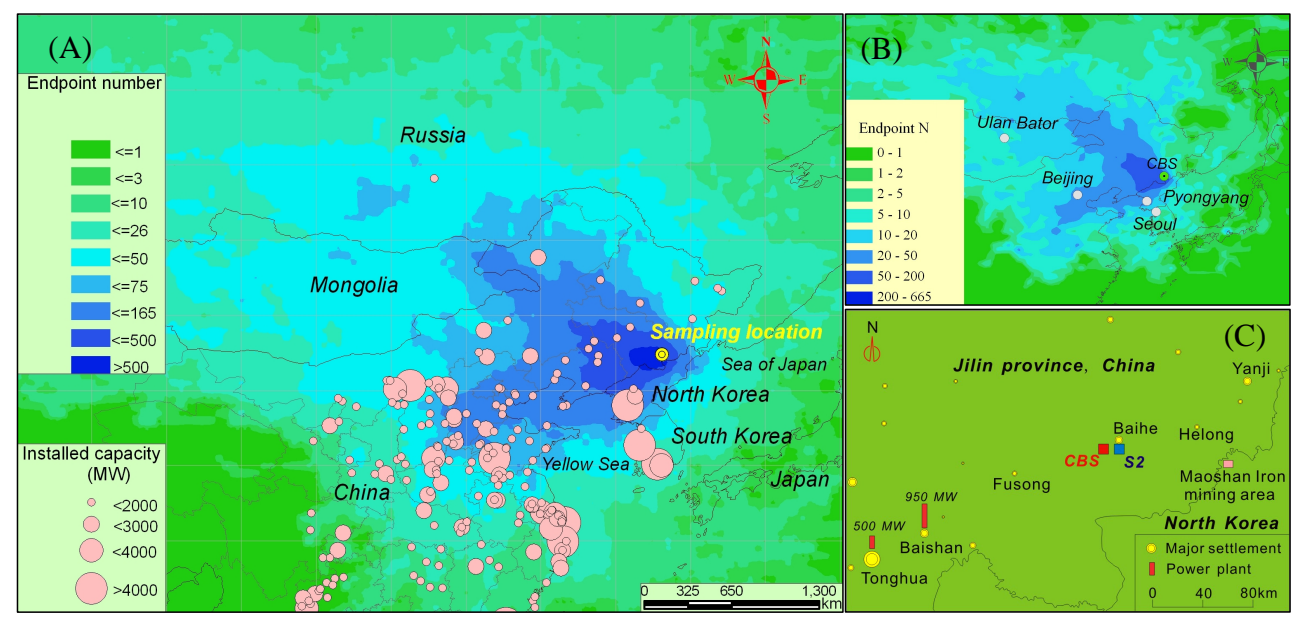

Fig. 1. Map showing (A) location of the sampling site CBS, large coal-fired power plants and air masses endpoints at CBS during the year of October 2008-October 2010; (B) air masses endpoints at the site of S2 during Aug. 2005-July 2006; and (C) locations of CBS and S2 as well as regional major settlements and large point sources in Mt. Changbai area.

East Asia tend to be comparatively elevated (Nguyen et al., 2007; Fu et al., 2008, 2010a, 2011; Wan et al., 2009; Ci et al., 2011). The spatial distribution of atmospheric TGM concentrations in remote areas world-wide generally coincides very well with the global anthropogenic $\mathrm{Hg}$ emission inventories (Wilson et al., 2006; Pacyna et al., 2011), indicating the anthropogenic $\mathrm{Hg}$ sources play a dominant role in the atmospheric TGM distributions.

East Asia is ranked as the world's largest anthropogenic source region of atmospheric $\mathrm{Hg}$, where in China the majority $(\sim 83 \%)$ of the emissions originates from coal combustion and non-ferrous smelting activities (Wu et al., 2006; Pirrone et al., 2010; Pacyna et al., 2011). The density of anthropogenic $\mathrm{Hg}$ emission in China displays a distinct regional distribution pattern with relatively higher emissions in Central, Eastern, Southern, and Southwestern China (Street et al., 2005; Wu et al., 2006). Long-term monitoring of TGM at remote sites is crucial to assess the regional atmospheric $\mathrm{Hg}$ budget. A study conducted in a remote region of Southwestern China showed a mean TGM concentration of $2.80 \pm 1.51 \mathrm{ng} \mathrm{m}^{-3}$ (Fu et al., 2010), which is highly elevated compared to the northern hemispherical background (1.5 1.7 $\mathrm{ng} \mathrm{m}^{-3}$, Lindberg et al., 2007; Valente et al., 2007). Long-term studies of atmospheric TGM are very limited in remote areas of China. Due to the impact of local emissions and strong regional sources, some of the previous studies tended to overestimate the regional background levels of atmospheric TGM (i.e. Fu et al., 2009; Wan et al., 2009). In the present study, we conducted two years of continuous measurements of atmospheric TGM at a remote site in Mt. Changbai area, Northeastern China. Based on this long-term data set, we discuss in this paper the impacts of local and regional sources on the observations. We have used a hybrid receptor model to identify the potential source regions and pathways that contributing to the elevated TGM concentrations in the study area via long-range transport.

\section{Experimental}

\subsection{Sampling locations}

The sampling site (CBS: $42^{\circ} 24^{\prime} 0.9^{\prime \prime} \mathrm{N}, 128^{\circ} 06^{\prime} 45^{\prime \prime} \mathrm{E}$, $741 \mathrm{~m}$ a.s.l) is operated by the Chinese Terrestrial Ecosystem Flux Research Network and situated about $40 \mathrm{~km}$ to the north of the major peak of Changbai mountain range (Fig. 1). This mountain range stretches more than $1000 \mathrm{~km}$ from southwest to northeast. During the calendar year of 2005-2006, Wan et al. (2009) carried out a one-year measurement of atmospheric TGM in the Open Research Station of Changbai Mountain Forest Ecosystem, Chinese Academy of Sciences (S2, Fig. 1c, $42^{\circ} 24^{\prime} 0.1^{\prime \prime} \mathrm{N}, 128^{\circ} 06^{\prime} 25^{\prime \prime} \mathrm{E}, 738.1 \mathrm{~m}$ a.s.l), which is located about $1.2 \mathrm{~km}$ to the west of the CBS station. The CBS site is located in a deciduous broad-leaf forest; whereas S2 is located in an open-air site $\left(\sim 5000 \mathrm{~m}^{2}\right)$ surrounded by deciduous broad-leaf forest. The sampling inlet of CBS was 2-3 $\mathrm{m}$ above forest canopy; whereas sampling inlet of S2 was mounted $2 \mathrm{~m}$ above the rooftop ( $5 \mathrm{~m}$ above surface ground) of a two-storey building and about $10 \mathrm{~m}$ from forest canopy.

Regions to the east and south of the sampling site consist of naturally preserved forest and mountainous areas without any significant sources of atmospheric pollutants, with the exception of a Maoshan iron mining situated $\sim 100 \mathrm{~km}$ to the east of CBS in North Korea. Most of the regional large point sources and major settlements are located to the west of the sampling site (Fig. 1c). For example, Baishan city, with a pollution of $\sim 300000$ and a large coal-fired power plant, are located $150 \mathrm{~km}$ southwest to the sampling site, and 
Tonghua city, with a population of 450000 and a large coalfired power plant, is located about $190 \mathrm{~km}$ southwest to the sampling site (Fig. 1c). Figure 1a shows the locations of large coal-fired power plants (incl. installed capacity $>1000 \mathrm{MW}$ ) in East Asia. Most of these large point sources are situated more than $300 \mathrm{~km}$ to the west and southwest of our study area. Baihe town (pop. $\sim 49000$ ), the major settlement in the study area, is located $\sim 1.4 \mathrm{~km}$ to the northeast of CBS and $\sim 0.5 \mathrm{~km}$ to the north of the site S2 (Fig. 1c). There were some domestic coal and biomass burning activities during the study period, which may constitute an important $\mathrm{Hg}$ source to the local atmospheric environment.

\subsection{TGM measurement method}

From 24 October 2008 to 31 October 2010, TGM concentration in ambient air was continuously monitored using an automated $\mathrm{Hg}$ vapor analyzer (Tekran 2537A). The operation of the instrument relying on pre-concentration of TGM onto gold traps, followed by thermal desorption, and detection of $\mathrm{Hg}^{0}$ by cold vapor atomic fluorescence spectrometry. The instrument features two gold cartridges working in parallel. While one cartridge is collecting TGM, the other one is performing analysis of the collected TGM. The function of the cartridges is then reversed, allowing continuous sampling of ambient air. The sampling inlet was mounted at a height of $2 \sim 3 \mathrm{~m}$ above the forest canopy by using a $25 \mathrm{~m}$ Teflon tube and a $15 \mathrm{~m}$ heated Teflon tube. Particulate matter in ambient air was removed using a 45-mm diameter Teflon filter (pore size $0.2 \mu \mathrm{m}$ ) upstream of the analyzer, which was replaced every two week. It should be noted that an unknown fraction of GOM in the TGM was likely lost during passing the 25-m un-heated Teflon tube due to its adsorption to tube inner surface and particles. However, it is not well known that how much percent of GOM was stuck by the sampling Teflon tube, and whether the stuck GOM could be transformed to GEM and sequentially determined by the $\mathrm{Hg}$ vapor analyzer. Since GOM generally constitutes a small fraction $(<1 \%)$ of TGM in ambient air and the loss of GOM only had very limited effect on measured atmospheric $\mathrm{Hg}$, we referred atmospheric Hg as TGM throughout the paper and just aimed to have a good accordance with TGM measurements in other literatures. The analyzer was programmed to measure atmospheric TGM at a time resolution of $5 \mathrm{~min}$ and at a sampling flow rate of $1.0 \mathrm{~L} \mathrm{~min}^{-1}$ (Sampling flow rate and volume are referenced to $0^{\circ} \mathrm{C}$ and $760 \mathrm{~mm} \mathrm{Hg}$ pressure). The detection limit of the analyzer is estimated to be $\sim 0.15 \mathrm{ng} \mathrm{m}^{-3}$ (Tekran 2002). The Tekran 2537A analyzer was calibrated automatically every $25 \mathrm{~h}$ by means of using the instrument's internal $\mathrm{Hg}$ permeation source. The emission rate of the permeation source was verified every $4 \sim 6$ months by performing manual injections of $\mathrm{Hg}^{0}$ by a syringe from an external Hg vapor source (Tekran 2505). During sampling, a standard addition unit (Tekran 1120) was employed to make real-time check of the measurements, and results from the standard ad- dition unit were comparable to the auto calibrations results (ratio $=1.08 \pm 0.10)$.

Hourly averaged meteorological parameters including wind speed and wind direction were obtained from the standard meteorological station at $\mathrm{S} 2$ site as such measurements were not available at CBS. Since S2 was located about $1.2 \mathrm{~km}$ from CBS, and the surrounding areas were characterized by flat terrain. We roughly speculate that the CBS and S2 had similar wind speed and wind direction during the study period.

\subsection{Potential Source Contribution Function (PSCF) analysis}

To identify the possible impacts of long-range transport on atmospheric TGM, 5-day backward trajectories arriving at CBS at a height of 500,1000, and $1500 \mathrm{~m}$ above ground level were calculated using a Geographical Information System based software (Wang et al., 2009) and gridded meteorological data (Global Data Assimilation System, GDAS1) from the U.S. National Oceanic and Atmospheric Administration (NOAA).

The calculated backward trajectories were used to make Potential Source Contribution Function (PSCF) analysis of atmospheric TGM at Mt. Changbai, which has been applied in many previous studies to identify possible source areas for the measured atmospheric pollutants (e.g. Kim et al., 2005; Choi et al., 2008). The PSCF values for the grid cells in the study domain were calculated by counting the trajectory segment endpoints that terminate within each cell. The number of endpoints that fall in the ijth cell is designated as $\mathrm{N}_{i j}$. The number of endpoints for the same cell corresponding to TGM concentrations higher than an arbitrarily set criterion (mean TGM concentration of $1.60 \mathrm{ng} \mathrm{m}^{-3}$ during the whole sampling campaign was used here) is defined to be $\mathbf{M}_{i j}$. The PSCF value for the ijth cell is then defined as:

$\mathrm{PSCF}_{i j}=\mathrm{M}_{i j} \div \mathrm{N}_{i j}$

Since backward trajectories starting at different heights traverse different distances and pathways, multiple height PSCF analysis was performed with starting elevations of 500, 1000, and $1500 \mathrm{~m}$ above ground level, respectively. The total endpoints in the geophysical region covered were 234998 and the geophysical region was divided into 9801 grid cells of $0.5 \times 0.5$ latitude and longitude. To reduce the effect of small values of $\mathrm{N}_{i j}$, the PSCF values were multiplied by an arbitrary weight function $\mathrm{W}_{i j}$ to better reflect the uncertainty in the values for these cells (Polissar et al., 2001). The weighting function reduced the PSCF values when the total number of the endpoints in a particular cell $\left(\mathrm{N}_{i j}\right)$ was less than about three times the average value of the end points per each cell:

$W_{i j}=\left\{\begin{array}{llll}1.0 & N_{i j} & >3 N_{\text {ave }} & \\ 0.70 & 3 N_{\text {ave }} & >N_{i j} & >1.5 N_{\text {ave }} \\ 0.40 & 1.5 N_{\text {ave }}>N_{i j} & >N_{\text {ave }} \\ 0.20 & N_{\text {ave }}>N_{i j} & \end{array}\right.$ 


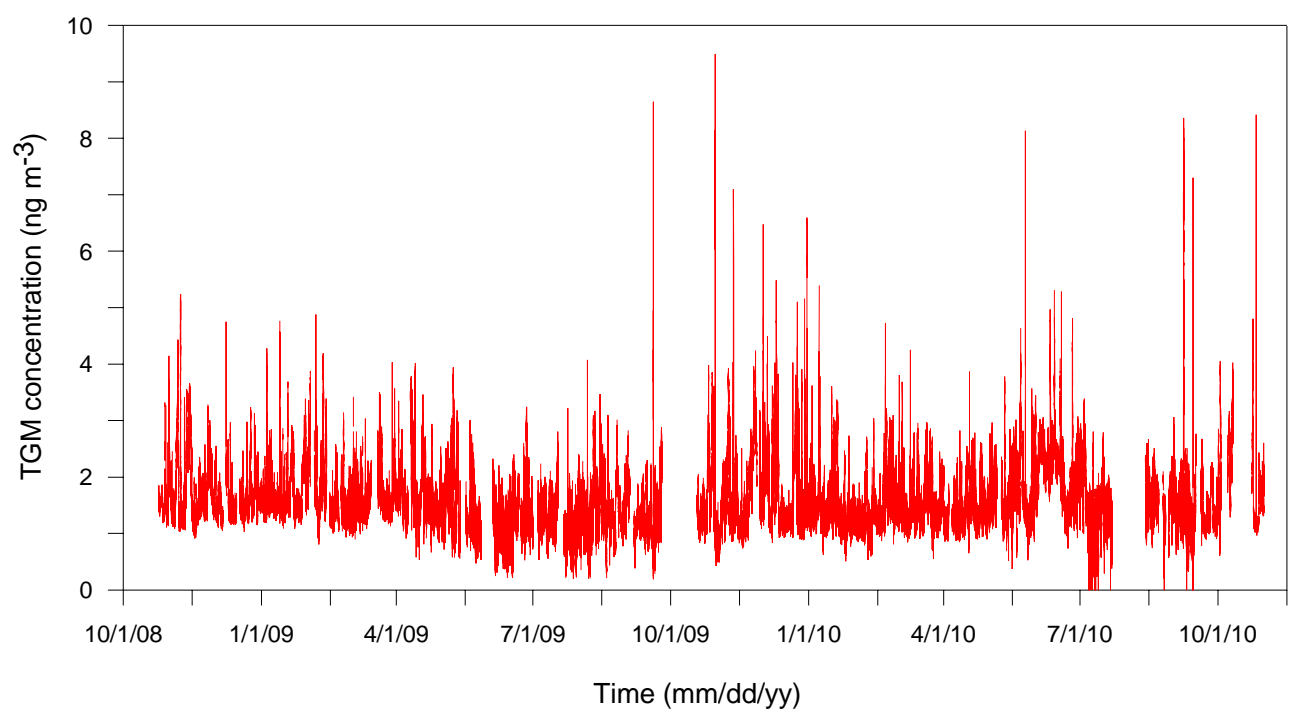

Fig. 2. Time series of 5-min averaged TGM concentrations at CBS.

\section{Results and discussion}

\subsection{Overall characteristics of TGM distribution in ambient air}

Figure 2 shows the time series of atmospheric TGM concentrations from 24 October 2008 to 31 October 2010 at CBS. The majority of the data $(75.5 \%)$ fell in the range of $1.0 \sim 2.0 \mathrm{ng} \mathrm{m}^{-3}$, which is commonly regarded as the values observed at remote sites in the Northern Hemisphere (Lindberg et al., 2007). However, episodes with elevated TGM concentrations were intermittently observed during the whole sampling campaign, by that $18.1 \%$ and $0.2 \%$ of the data exceeded the level of 2.0 and $4.0 \mathrm{ng} \mathrm{m}^{-3}$, respectively. This indicates the sampling site was occasionally impacted by $\mathrm{Hg}$-enriched air masses originated from source areas in Mt. Changbai area and/or other source regions of China.

Averaged TGM concentration at CBS was $1.60 \pm 0.51 \mathrm{ng} \mathrm{m}^{-3}$ (median: $1.48 \mathrm{ng} \mathrm{m}^{-3}$ ). This level is significantly lower than other observations conducted at rural sites in Chinese mainland, such as: Mt. Waliguan in Northwestern China (1.98 $\pm 0.98 \mathrm{ng} \mathrm{m}^{-3}$, Fu et al., 2012), Mt. Leigong in Southwestern China $\left(2.80 \pm 1.51 \mathrm{ng} \mathrm{m}^{-3}, \mathrm{Fu}\right.$ et al., 2010), Shangri-La observatory in Southwestern China $\left(2.59 \pm 1.33 \mathrm{ng} \mathrm{m}^{-3}\right.$, Zhang et al., 2011), and Chengshantou marine station in Eastern China $\left(2.31 \pm 0.74 \mathrm{ng} \mathrm{m}^{-3}, \mathrm{Ci}\right.$ et al., 2011), but is comparable or slightly lower than those observed from remote areas in Europe and North America. Choi et al. (2008) and Mao et al. (2008) reported annual mean TGM concentrations of $1.4 \pm 0.4 \mathrm{ng} \mathrm{m}^{-3}$ and $1.42 \pm 0.15 \mathrm{ng} \mathrm{m}^{-3}$ at two forest-surrounded sites in Northeastern America, respectively. Long-term continuous measurements of TGM concentrations from the Canadian Atmospheric Mercury Measurement Network (CAMNet) showed that mean TGM concentrations were in the range of $1.36-1.78 \mathrm{ng} \mathrm{m}^{-3}$ (Temme et al., 2007). In Europe, continuous monitoring of TGM at Mace Head station, Ireland since 1995 exhibited a consistent decreasing trend during the last decade, with the mean concentrations of $1.41 \mathrm{ng} \mathrm{m}^{-3}$ and $1.56 \mathrm{ng} \mathrm{m}^{-3}$ observed in 2008 and 2009 (Ebinghaus et al., 2011; Slemr et al., 2011).

Our result also compares favourably with the TGM level predicted from modelling studies (Lin et al., 2010; Li et al., 2010). The relatively low TGM level observed at CBS can be explained by a combination of factors. First of all, the study area is relatively isolated from dominant source regions of China. As can be seen from Fig. 1a, most of the large coal-fired power plants (>1000 MW) are located more than $200 \mathrm{~km}$ from the sampling site. Large industrial centres and urban areas associated with significant anthropogenic $\mathrm{Hg}$ emissions are located more than $100 \mathrm{~km}$ from the study area (Baihe town was found to have a limited effect on TGM levels at CBS site, which will be further discussed in Sect. 3.2). Moreover, many air masses ended at CBS were originated from northern Inner Mongolia of China, Western Mongolia, and Siberia of Russia (Fig. 1a), which are generally regarded as regions with relatively low anthropogenic $\mathrm{Hg}$ emissions (Wilson et al., 2006; Pacyna et al., 2010). It should be also pointed out that dry deposition of TGM to forest canopy was probably an additional reason for low TGM level observed at CBS. Many studies suggested that TGM in ambient air is the predominant source of $\mathrm{Hg}$ in forest leaves and forest canopy could be an important sink of atmospheric TGM (e.g. Zhang et al., 2005; Poissant et al., 2008; Fu et al., 2010). Since the sampling tube inlet was installed closely $(2-3 \mathrm{~m})$ to forest canopy in this study, and adsorption of TGM by forest leaves might partially contribute to the relatively lower levels of TGM observed at CBS station. 

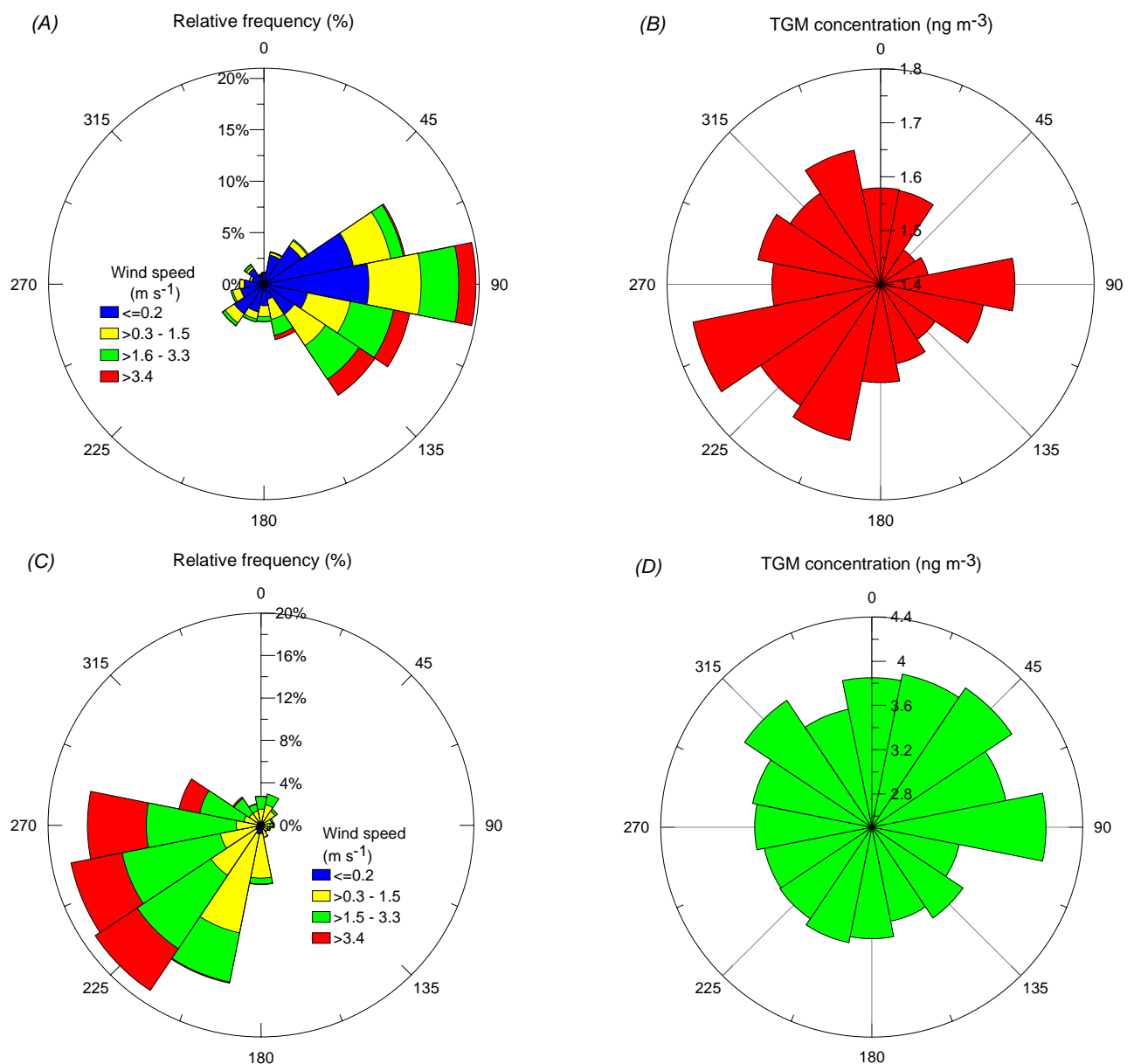

Fig. 3. (A) Wind rose at CBS during the whole study period (Oct 2008 to October 2010); (B) directional dependence of TGM at CBS (October 2008 to October 2010); (C) wind rose at S2 during the calendar year of August 2005-July 2006; and (D) directional dependence of TGM at S2 (August 2005-July 2006).

\subsection{A comparison to a previous monitoring at S2: implication of long-range transport, regional and local impacts}

During the period of August 2005-July 2006, Wan et al. (2009) carried out one year of TGM measurements at the site $\mathrm{S} 2(\sim 1.2 \mathrm{~km}$ to the west of CBS, cf. Figs. 1a and b). The overall geometric mean TGM concentration at $\mathrm{S} 2$ was $3.58 \pm 1.78 \mathrm{ng} \mathrm{m}^{-3}$ (median: $3.15 \mathrm{ng} \mathrm{m}^{-3}$ ), which is more than twofold higher compared to the present study. Given the proximity between the stations, we speculate that the significant inter-stational difference in TGM concentrations was mostly due to an abrupt temporal shift in the source strength of the regional and local sources.

Figure $3 \mathrm{a}$ and $\mathrm{b}$ display the wind rose and TGM concentration distribution as a function of wind direction at CBS, respectively. During the study period of 2008-2010, most of the surface air flows were derived from an easterly sector; whereas air flows from southwest to northeast passing over the major regional sources, accounted for relatively lower frequencies. TGM concentrations exhibited a strong dependence on wind directions at CBS. As shown in Fig. 3b, wind flows from the southwestern sector were frequently associated with elevated TGM concentrations (1.6-1.8 $\mathrm{ng} \mathrm{m}^{-3}$ ) than other sectors. This corresponds very well with the locations of two largest coal-fired power plants and large cities to the southwest of the sampling site (Fig. 1c). However, it should be pointed out that these sources to the southwest were not likely to contribute significantly to the sampling site, mainly because air flows from southwest constituted a small portion of the total wind sectors during the study period. On the other hand, air flows from north to west and south showed relatively low TGM concentrations of $1.4 \sim 1.6 \mathrm{ng} \mathrm{m}^{-3}$ (Fig. 3b), with the exception of easterly flow. The slightly elevated TGM mean concentrations associated with easterly flow can potentially be attributed to $\mathrm{Hg}$ emissions from Maoshan iron mining area in the north of North Korea. This mining area is one of the largest opencast operating iron mining areas in the Northeast Asia located $\sim 100 \mathrm{~km}$ to the east of CBS (Fig. 1). As air flows from 


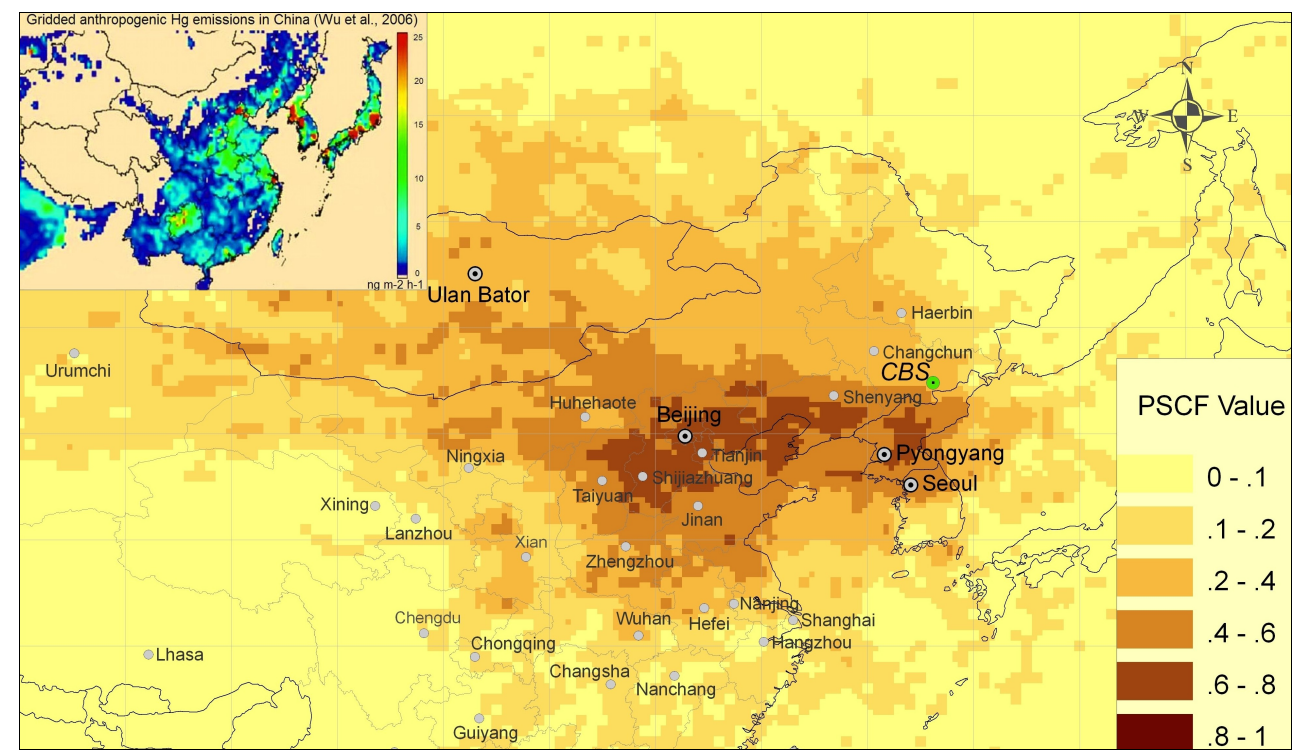

Fig. 4. Likely potential source areas of TGM identified by PSCF analysis at CBS for the whole study period.

east direction were most abundant, $\mathrm{Hg}$ emissions from the mining area likely had a notable impact on the TGM observations at CBS. On the contrary, we were not able to identify elevated TGM concentrations associated with air flows originated from and/or passed over Baihe town.

Effects of long range transport $(>200 \mathrm{~km}$ ) of air pollutants on the TGM level at CBS were evaluated by using the PSCF analysis. As shown in Fig. 4, Beijing, Tianjin, northwestern Shanxi, northwestern Shandong, Hebei, and southern Liaoning provinces in Northern China as well as the south of North Korea are identified as potential source regions and pathways for the CBS sampling site. The identified source areas correspond very well with the anthropogenic $\mathrm{Hg}$ emission inventory in Eastern Asia (Fig. 4). Northern Central China including Beijing, Tianjin, Shanxi, Hebei, Shandong, and Liaoning is an important anthropogenic source region of China, and it is predicted that 140 tons of $\mathrm{Hg}$ was emitted to the atmosphere in 2003 (Wu et al., 2006). There is a lack of studies of ambient TGM in this region. However, a monitoring survey of TGM at rural, suburban, and urban sites of Beijing municipality revealed elevated levels (means ranged from 3.1 to $24.7 \mathrm{ng} \mathrm{m}^{-3}$ ) of TGM, indicating significant anthropogenic $\mathrm{Hg}$ emissions in this area (Liu et al., 2002). The potential area identified in Southern North Korea includes several large coal-fired power plants (Fig. 1) and is also classified as a high anthropogenic $\mathrm{Hg}$ emission region by $\mathrm{Hg}$ emission inventory (e.g. Shetty et al., 2008; Wilson et al., 2006; Pacyna et al., 2010). Northern Bohai Sea was also identified as a potential source region to the CBS during the study period. We conclude that this is mainly resulted from anthropogenic $\mathrm{Hg}$ emissions from surrounding areas of Bohai Sea. As shown in Fig. 1a, there are a number of large coal-fired power plants in the coastal areas of Bohai Sea. Also, the coastal areas of Bo- hai Sea are densely populated and have many typical industrial $\mathrm{Hg}$ sources (e.g. large Zinc plants, chlor-alkali plants, Wang et al., 2009; Li et al., 2010), which may contribute to significant atmospheric $\mathrm{Hg}$-enriched plumes.

In contrast, TGM concentrations at S2 from August 2005 to Jul 2006 were mainly affected by regional and local sources. As shown in Fig. 3c, surface winds at S2 showed a quite different distribution pattern with CBS, with southwest as the predominant wind direction. Since most of the regional sources were located to the southwest of the sampling site, the predominant southwesterly flow plausibly contributed to the elevated levels of TGM at S2.

Emissions of $\mathrm{Hg}$ from coal and biomass burning in the station and the Baihe town also played an important role in TGM distribution at S2. The Changbai mountain forest ecosystem research station is generally open to the scientific researchers during summer season (July to September, Opening season). During the opening season, coal and biomass burning for cooking was prevalent and released $\mathrm{Hg}$ to the atmosphere. As shown in Fig. 5, TGM concentrations at S2 during the opening season varied significantly and exhibited a much higher mean TGM concentration (mean $4.49 \pm 2.44 \mathrm{ng} \mathrm{m}^{-3}$ ) compared to other seasons (mean $3.02 \pm 1.44 \mathrm{ng} \mathrm{m}^{-3}$ ), indicating the significant impact of $\mathrm{Hg}$ emissions deriving from inside the research station area. Nevertheless, in the study of Wan et al. (2009), the highest mean TGM concentrations at S2 were observed under northerly to westerly flow patterns (Fig. 3d), which is not consistent with the results obtained at CBS. This indicates that, unlike the site of CBS in this study, Hg emissions from Baihe town likely had a notable impact at $\mathrm{S} 2$. This is mainly because $\mathrm{S} 2$ was located much more close $(\sim 0.5 \mathrm{~km})$ to the Baihe town compared to CBS $(\sim 1.4 \mathrm{~km})$ in the present 


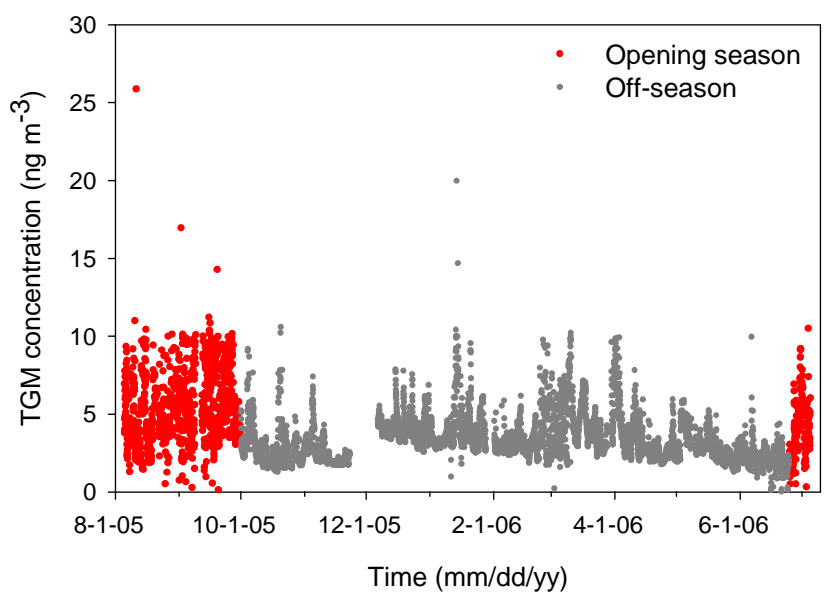

Fig. 5. Time series of hourly mean TGM concentrations at S2 from August 2005 to July 2006.

study. Partially, it is also plausible that the domestic coal and biomass burning in recent years has been decreased to yield lower emissions. In general, coal and biomass burning during cold season is prevalent in many areas of China. This source has strong seasonal variations with enhanced emissions in cold months and could play an important role in local atmospheric Hg budget. Previous study by Fu et al. (2009) in Southwestern China revealed that such source resulted in a $25 \%\left(\sim 2 \mathrm{ng} \mathrm{m}^{-3}\right)$ increase of atmospheric TGM concentration in the downwind of a major settlement. As shown by Wan et al. (2009), elevated TGM concentrations were observed during cold months at S2, which was partially attributed to $\mathrm{Hg}$ emissions from Baihe town.

The PSCF result regarding the observational study at S2 suggests a significant impact from local and regional sources. As shown in Fig. 6, a small region to the north and south of the sampling site were modelled with the highest PSCF values. However, this region has a relatively sparse population and there is no significant point source. The high PSCF value generated in this area might be probably due to the trailing effect. In general, PSCF analysis could give a constant weight along the path of trajectories. Therefore, areas downwind and upwind actual source regions are also likely to be identified as potential source regions. As discussed above, Baihe town, located closely to the north of S2, contributed significantly to the high levels of TGM at S2. This local source could be probably responsible to high PSCF value in the region to the north of the sampling site S2.

Impact of regional emissions from Baishan and Tonghua on the CBS and S2 was not clearly identified by the PSCF results. It is speculated that $\mathrm{Hg}$ released from Baishan and Tonghua urban areas was mainly carried to the sampling sites via local surface wind system, which may not coincide very well with directions of backward trajectories. Overall, the indentified potential source areas at S2 do not correspond very well with anthropogenic $\mathrm{Hg}$ emission inventory in Northeast- ern and Northern China. We suggested that local and regional sources might play a predominant role in TGM distribution at S2 during the sampling campaign, whereas effects from long-range transport might be less important. Moreover, it also indicates that observations made at sites impacted by strong local and regional sources are less suitable to identifying potential source and pathways of pollutants using PSCF method.

\subsection{Temporal trends of TGM at CBS}

TGM concentrations showed clear diurnal variations at CBS. As shown in Fig. 7, TGM concentrations during all the seasons tended to increase after sunrise (05:00 06:00 in local time), with the highest concentrations observed before noon, and then decreased throughout the afternoon and the whole night. This is consistent with the observations conducted at rural sites in Mt. Leigong and Mt. Gongga. The surface wind system at CBS was partially controlled by mountain and valley breeze, with air flows from surrounding low-altitude areas during daytime and from mountain peaks during night, respectively. We conclude that the elevated TGM concentrations during daytime were plausibly attributable to the impact of regional sources. During night, TGM concentrations in ambient air of the industrial and urban areas probably increased due to the significant $\mathrm{Hg}$ emissions under shallow nocturnal boundary layer conditions (Lee et al., 1998; Feng et al., 2004). The Hg-enriched air masses from regional source areas could be transported to the sampling site via upslope air movements and caused elevated TGM concentrations during daytime. The peaks observed before noon were probable due to the encounters of plumes from coal-fired power plants and urban areas, while decrease of TGM in the afternoon was likely caused by enhanced vertical atmosphere movement which diluted the regional atmospheric TGM concentrations.

The diurnal pattern of TGM was especially pronounced during summer, with significantly lower nighttime TGM concentrations compared to other seasons. We speculate that this is mainly linked to downslope flows originated from free troposphere, which may have much lower GEM concentrations due to the fast oxidation of GEM by ozone, $\mathrm{OH}$, or possible other oxidants under dry air conditions (Swartzendruber et al., 2006; Faïn et al., 2009; Slemr et al., 2009). Also, deposition of TGM to vegetation foliar under shallow nocturnal boundary layer conditions during leaf-growing season might play an additional effect to decrease night TGM concentrations (Poissant et al., 2008).

TGM concentrations did not show a consistent seasonal pattern at CBS during the calendar years of 20082009 and 2009-2010. As shown in Fig. 8, the highest monthly value was observed in June 2010, with the mean of $2.14 \mathrm{ng} \mathrm{m}^{-3}$. However, the monthly mean TGM concentration $\left(1.27 \mathrm{ng} \mathrm{m}^{-3}\right)$ in June 2009 was relatively lower compared to other months. Additionally, during the first 


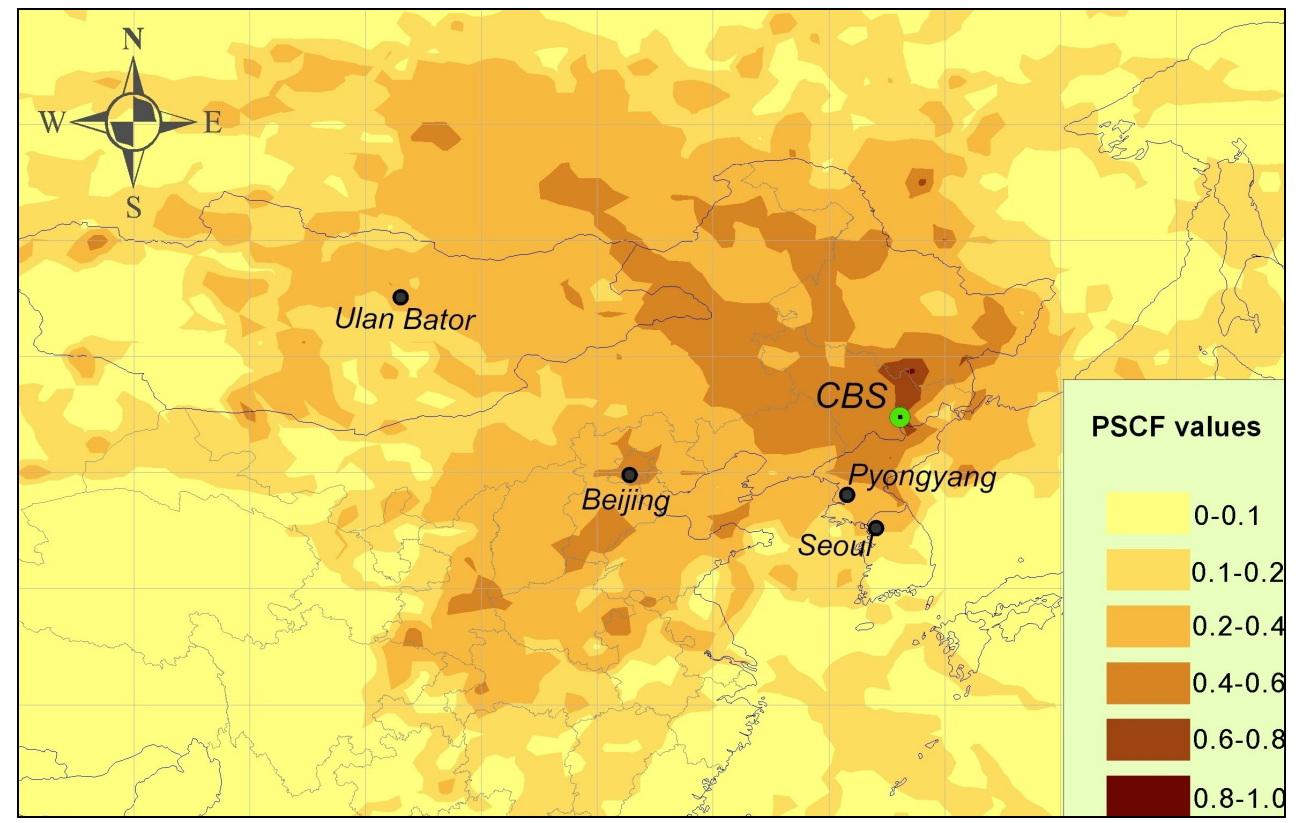

Fig. 6. Likely potential source areas of TGM at S2 during August 2005-July 2006.

Table 1. Summary of TGM concentrations $\left(\mathrm{ng} \mathrm{m}^{-3}\right)$ at CBS.

\begin{tabular}{lcccccrrr}
\hline & Mean & Median & Std & 10th & 90th & Range & $N$ \\
\hline Spring & 1.61 & 1.51 & 0.45 & 1.16 & 2.20 & $0.37-8.13$ & 43371 \\
Summer & 1.52 & 1.45 & 0.56 & 0.90 & 2.33 & $<$ Dl-5.31 & 37821 \\
Autumn & 1.64 & 1.45 & 0.64 & 1.04 & 2.42 & $<$ D1-9.50 & 37363 \\
Winter & 1.61 & 1.48 & 0.47 & 1.16 & 2.24 & $0.51-6.60$ & 45615 \\
Total & 1.60 & 1.48 & 0.51 & 1.08 & 2.29 & $<$ Dl-9.50 & 164170 \\
\hline
\end{tabular}

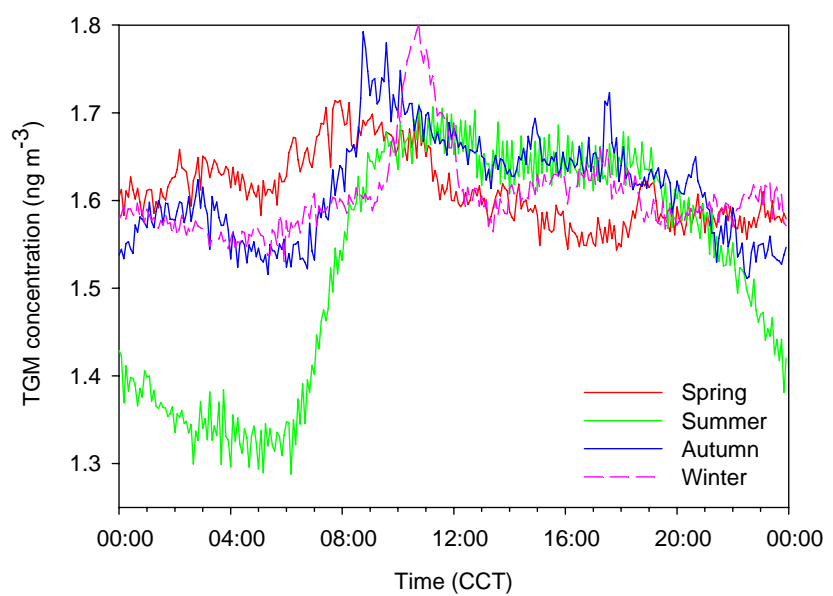

Fig. 7. Diurnal variations of TGM at CBS during the whole study period.

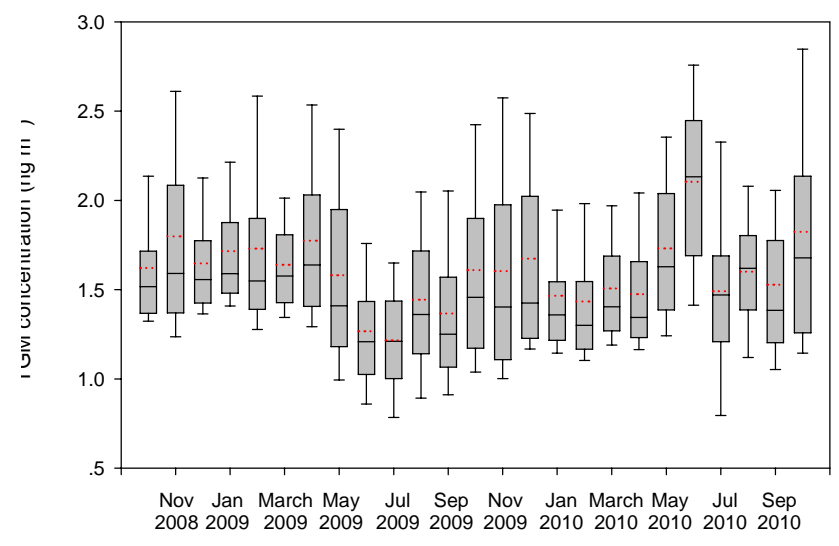

Fig. 8. Monthly variations of TGM at CBS. Box horizontal solid lines show 25th, 50th, and 75th percentiles, dotted line within each box indicates mean TGM concentration, and whiskers represent 10th and 90th percentiles of TGM concentration. 

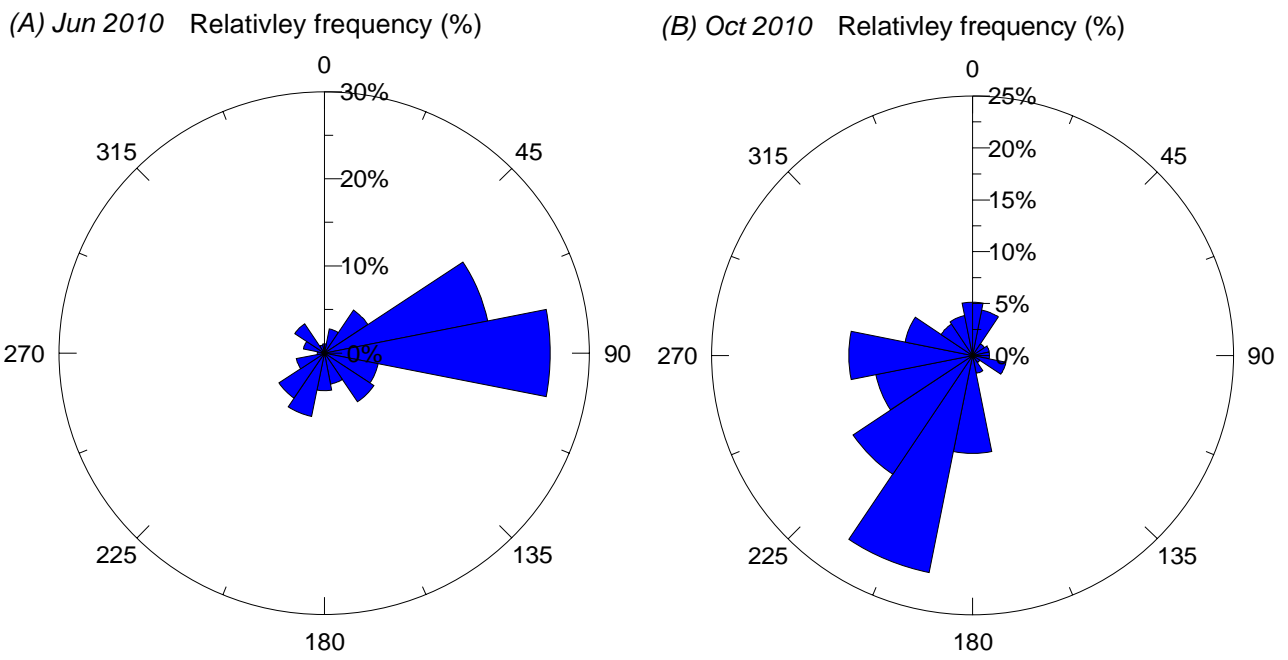

Fig. 9. Wind roses at CBS in (A) June 2010 and (B) October 2010.
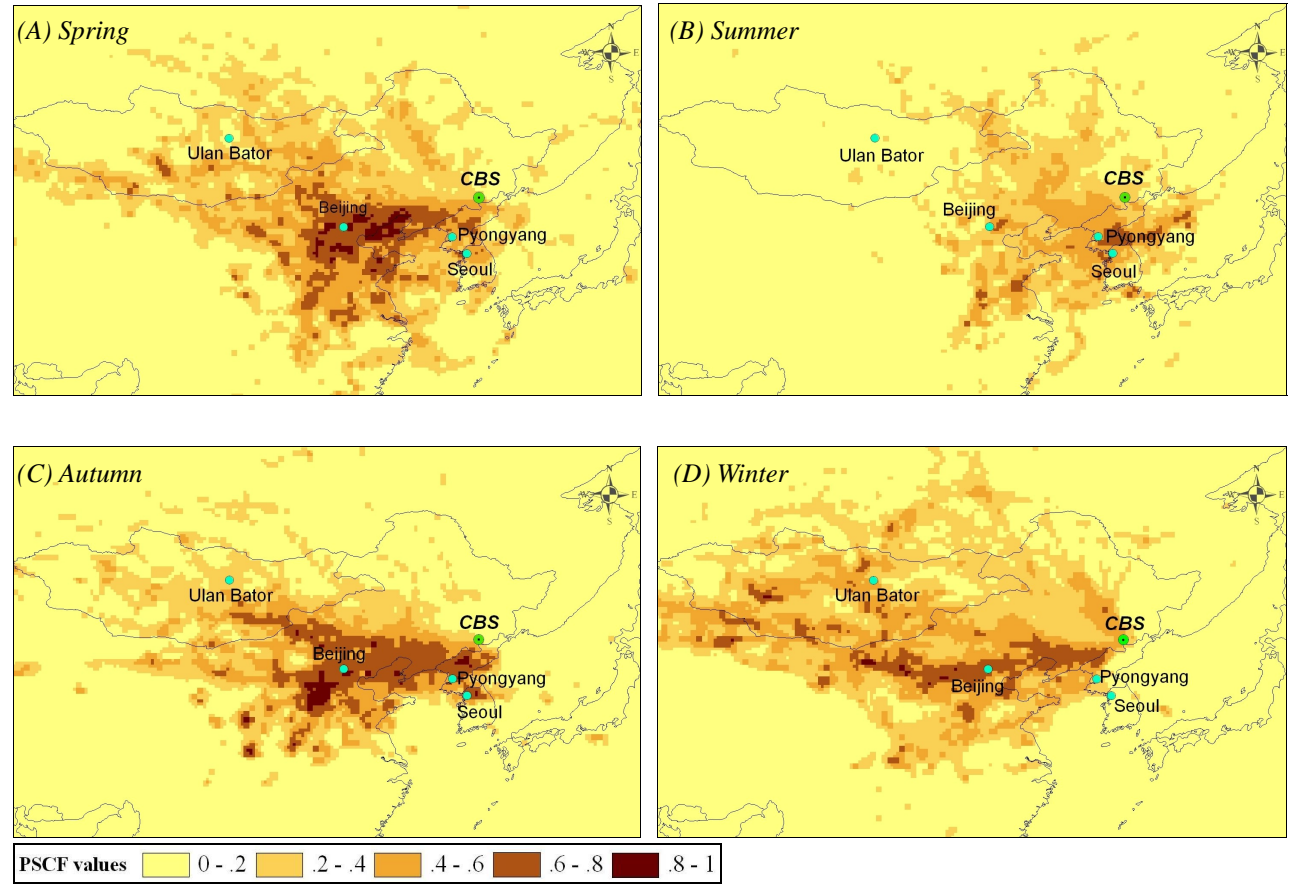

Fig. 10. Seasonal PSCF results of TGM at CBS.

year, months during cold seasons generally showed relatively higher TGM concentrations; while TGM concentrations were relatively lower in the cold seasons of the second year (Fig. 8). The monthly variations of TGM at CBS was quite different from the studies in Southwestern and Southern China (Feng et al., 2004; Fu et al., 2008, 2010), which showed highly elevated TGM concentrations in cold seasons related to enhanced local and regional coal combustions. We examined the wind roses during June and October 2010 in which monthly mean TGM concentrations were observed (2.14 and $1.92 \mathrm{ng} \mathrm{m}^{-3}$, respectively). It is shown that surface wind flows in these two months were mostly from directions linked to the regional sources as aforementioned (Fig. 9). This indicates variations of predominant wind directions, which might change sources-receptor relationships in the study area, played an important role in influencing monthly TGM variations.

Long-range transport was also responsible for the seasonal variations of TGM at CBS. Figure 10 shows the seasonal PSCF results at CBS. It is shown that the CBS was mostly impacted by anthropogenic Hg emissions from Beijing, Tianjin, Hebei and Liaoning during spring and autumn sampling 
campaigns (Fig. 10a and c), and this is likely contributable to elevated mean TGM concentrations in spring and autumn during the whole study period (Table 1). In winter, north of Shanxi province was calculated with the highest PSCF value (Fig. 10d), and this is probably linked to $\mathrm{Hg}$ emission from the large coal-fired power plants in this area (Fig. 1a). Impact of long-range transport from strong source regions of Northern China tended to decrease in summer, partially because the study area was controlled by the southeast monsoon which brought air masses from ocean areas. On the other hand, the dominant southeast monsoon also carried anthropogenic $\mathrm{Hg}$ emission from Korean Peninsula which might be an important source region to the CBS during summer season (Fig. 10b).

\section{Conclusions}

In this study, we conducted a two years (October 2008October 2010) of continuous measurement of atmospheric TGM at a remote site in Mt. Changbai area, Northeastern China. The mean concentration during the whole sampling campaign was $1.60 \pm 0.51 \mathrm{ng} \mathrm{m}^{-3}$. This value is comparable to the values observed from remote areas in the Northern hemisphere, whereas it is much lower than those observed from remote sites in Southwestern, Northeastern, Southern, and Eastern China, likely indicating relatively lower anthropogenic $\mathrm{Hg}$ emissions in the Northeastern China and Asia. TGM level in the present study is much lower than the mean concentration $\left(3.58 \pm 1.78 \mathrm{ng} \mathrm{m}^{-3}\right)$ observed at the other site in the study area during the period between August 2005 and July 2006. We found that relative frequencies of surface wind flows were quite different during these two study periods, with east as the predominant wind direction in the present study (October 2008-October 2010) and southwest in the previous study (August 2005-July 2006), respectively. The highly elevated TGM concentrations for the previous study were probably resulted from more pronounced impacts of regional sources which mostly situated to the southwest of the study area. Besides, the measurement in the previous study was also impacted by coal and biomass $\mathrm{Hg}$ emissions from the sampling site and a major settlement nearby.

Both regional sources and long-range transport impacted the distribution of TGM in ambient air at CBS; whereas the effect from local sources was minimal. Regional sources included two large power plants and urban areas situated more than $150 \mathrm{~km}$ to the southwest, and an iron mining area situated $100 \mathrm{~km}$ to the east of the sampling site. The regional sources controlled the diurnal distributions of TGM at CBS which showed elevated levels during daytime, and also contributed significantly to the monthly variations of TGM. Long-range transported $\mathrm{Hg}$ was mostly originated from Beijing, Tianjin, northwestern Shanxi, northwestern Shandong, Hebei, and southern Liaoning, which were generally regarded as important source regions in China.
Acknowledgements. This research was financially supported by INCAPTA project under IPY, Chinese Academy of Science (KZCX2-EW-QN-111), and National Science Foundation of China (41003051, 40973086). The authors would like to acknowledge Environment Canada for offering the sampling instruments, and many thanks to A. Steffen and Patrick Lee from Environment Canada for their assistance in technique problems. We thank the Open Research Station of Changbai Mountain Forest Ecosystem, CAS for provide the monitoring platform and meteorological parameters, and Hao Xu, Guanhua Dai together with other engineers in the open station who contributed to the mercury measurements.

Edited by: J. H. Seinfeld

\section{References}

Brunke, E. G., Labuschagne, C., Ebinghaus, R., Kock, H. H., and Slemr, F.: Gaseous elemental mercury depletion events observed at Cape point during 2007-2008, Atmos. Chem. Phys., 10, 11211131, doi:10.5194/acp-10-1121-2010, 2010.

Choi, H. D., Holsen T. M., and Hopke, P. K.: Atmospheric mercury $(\mathrm{Hg})$ in the Adirondacks: Concentrations and sources, Environ. Sci. Technol., 42, 5644-5653, 2008.

Ci, Z. J., Zhang, X. S., Wang, Z. W., Niu, Z. C., Diao, X. Y., and Wang, S. W.: Distribution and air-sea exchange of mercury $(\mathrm{Hg})$ in the Yellow Sea, Atmos. Chem. Phys., 11, 2881-2892, doi:10.5194/acp-11-2881-2011, 2011.

Ebinghaus, R., Jennings, S. G., Kock, H. H., Derwent, R. G., Manning, A. J., and Spain, T. G.: Decreasing trends in total gaseous mercury observations in baseline air at Mace Head, Ireland from 1996 to 2009, Atmos. Environ., 45, 3475-3480, 2011.

Engle, M. A., Tate, M. T., Krabbenhoft, D. P., Schauer, J. J., Kolker, A., Shanley, J. B., and Bothner, M. H.: Comparison of atmospheric mercury speciation and deposition at nine sites across central and eastern North America, J. Geophys. Res., 115, D18306, doi:10.1029/2010JD014064, 2010.

Faïn, X., Obrist, D., Hallar, A. G., Mccubbin, I., and Rahn, T.: High levels of reactive gaseous mercury observed at a high elevation research laboratory in the Rocky Mountains, Atmos. Chem. Phys., 9, 8049-8060, doi:10.5194/acp-9-8049-2009, 2009.

Feng, X., Shang, L., Wang, S., Tang, S., and Zheng, W.: Temporal variation of total gaseous mercury in the air of Guiyang, China, J. Geophys. Res., 109, D03303, doi:10.1029/2003JD004159, 2004.

Fu, X. W., Feng, X. B., Zhu, W. Z., Wang, S. F., and Lu, J.: Total gaseous mercury concentrations in ambient air in the eastern slope of Mt. Gongga, South-Eastern fringe of the Tibetan plateau, China, Atmos. Environ., 42, 970-979, 2008.

Fu, X. W., Feng, X. B., Wang, S. F., Rothenberg, S., Shang, L. H., Li, Z. G., and Qiu, G. L.: Temporal and spatial distributions of total gaseous mercury concentrations in ambient air in a mountainous area in southwestern China: Implications for industrial and domestic mercury emissions in remote areas in China, Sci. Total. Environ., 407, 2306-2314, 2009.

Fu, X. W., Feng, X., Dong, Z. Q., Yin, R. S., Wang, J. X., Yang, Z. R., and Zhang, H.: Atmospheric gaseous elemental mercury (GEM) concentrations and mercury depositions at a high-altitude mountain peak in south China, Atmos. Chem. Phys., 10, 24252437, doi:10.5194/acp-10-2425-2010, 2010. 
Fu, X. W., Feng, X. B., Liang, P., Deliger, Zhang, H., Ji, J., and Liu, P.: Temporal trend and potential sources of speciated atmospheric mercury at Waliguan GAW station, northwestern China, Atmos. Chem. Phys., 12, 1951-1964, doi:10.5194/acp-12-19512012, 2012.

Kellerhals, M., Beauchamp, S., Belzer, W., Blanchard, P., Froude, F., Harvey, B., McDonald, K., Pilote, M., Poissant, L., Puckett, K., Schroeder, B., Steffen, A., and Tordon, R.: Temporal and spatial variability of total gaseous mercury in Canada: results from the Canadian Atmospheric Mercury Measurement Network (CAMNet), Atmos. Environ., 37, 1003-1011, 2003.

Kim, E., Hopke, P. K., Henski, M., and Koerber, M.: Source of fine particles in a rural Midwestern U.S., area, Environ. Sci. Technol., 39, 4953-4960, 2005.

Kock, H. H., Bieber, E., Ebinghaus. R., Spain, T. G., and Thees, B.: Comparison of long-term trends and seasonal variations of atmospheric mercury concentrations at the two European coastal monitoring stations Mace Head, Ireland and Zingst, Germany, Atmos. Environ., 39, 7549-7556, 2005.

Lee, D. S., Dollard, G. J., and Pepler, S.: Gas-phase mercury in the atmosphere of the United Kingdom, Atmos. Environ., 32, 855864, 1998.

Li, G. H., Feng, X. B., Li, Z. G., Qiu, G. L., Shang, L. H., Liang, P., Wang, D. Y., and Yang. Y. K.: Mercury emission to atmosphere from primary $\mathrm{Zn}$ production in China, Sci. Total Environ., 408, 4607-4612, 2010.

Li, P., Lin, C. J., Carmichael, G. R., Street, D. G., Tang, Y. H., Woo, J. H., Shetty, S. K., Chu, H. W., Ho, T. C., Friedli, H. R., and Feng, X. B.: Study of atmospheric Hg budget in East Asia using STEM-Hg modeling system, Sci. Total. Environ., 408, 32773291, 2010.

Lin, C. J., Pan, L., Streets, D. G., Shetty, S. K., Jang, C., Feng, X., Chu, H. -W., and Ho, T. C.: Estimating mercury emissions outflow from East Asia using CMAQ-Hg, Atmos. Chem. Phys., 10, 1853-1864, doi:10.5194/acp-10-1853-2010, 2010.

Lindberg, S., Bullock, R., Ebinghaus, R., Engstrom, D., Feng, X., Fitzgerald, W., Pirrone, N., Prestbo, E., and Seigneur, Ch.: A synthesis of progress and uncertainties in attributing the sources of mercury in deposition, Ambio., 36, 19-32, 2007.

Liu, S., Nadim, F., Perkins, C., Carley, R. J., Hoag, G. E., Lin, Y. H., and Chen, L. T.: Atmospheric mercury monitoring survey in Beijing, China, Chemos., 48, 97-107, 2002.

Mao, H., Talbot, R. W., Sigler, J. M., Sive, B. C., and Hegarty, J. D.: Seasonal and diurnal variations of $\mathrm{Hg} 0$ over New England, Atmos. Chem. Phys., 8, 1403-1421, doi:10.5194/acp-8-1403-2008, 2008.

Nguyen, H. T., Kim, K. H., Kim, M. Y., Hong, S., Youn, Y. H., Shon Z. H., and Lee, J. S.: Monitoring of atmospheric mercury at a Global Atmospheric Watch (GAW) site on An-Myun Island, Korea, Water Air Soil Pollut., 185, 149-164, 2007.

Pacyna, E. G., Pacyna, J. M., Sundseth, K., Munthe, J., Kindbom, K., Wilson, S., Steenhuisen, F., and Maxon, P.: Global emission of mercury to the atmosphere from anthropogenic sources in 2005 and projections of 2020, Atmos. Environ., 44, 2484-2499, 2010.

Pirrone, N., Cinnirella, S., Feng, X., Finkelman, F. B., Friedli, H. R., Leaner, J., Mason, R., Mukherjee, A. B., Stracher, G. B., Streets, D. G., and Telmer, K.: Global mercury emissions to the atmosphere from anthropogenic and natural sources, Atmos. Chem.
Phys., 10, 5951-5964, doi:10.5194/acp-10-5951-2010, 2010.

Poissant, L., Pilote, M., Beauvais, C., Constant, P., and Zhang, H. H.: A year of continuous measurements of three atmospheric mercury species (GEM,RGM and Hgp) in southern Québec, Canada, Atmos. Environ., 39, 1275-1287, 2005.

Poissant, L., Pilote, M., Yumvihoze, E., and Lean, D.: mercury concentrations and foliage.atmosphere fluxes in a maple forest ecosystem in Québec, Canada, J. Geophys. Res., 113, D10307, doi:10.1029/2007JD009510, 2008.

Polissar, A. V., Hopke, P. K., and Harris, J. M.: Source regions for atmospheric aerosol measured at Barrow, Alaska, Environ. Sci. Technol., 35, 4214-4226, 2001.

Schroeder, W. H. and Munthe, J.: Atmospheric mercury - an overview, Atmos. Environ., 5, 809-822, 1998.

Shetty, S. K., Lin, C. J., Streets, D. G., and Jang, C.: Model estimate of mercury emission from natural sources in East Asia, Atmos. Environ., 42, 8674-8685, 2008.

Slemr, F., Brunke, E. G., Labuschagne, C., and Ebinghaus, R.: Total gaseous mercury concentrations at the the Cape Point GAW station and their seasonality, Geophys. Res. Lett., 35, L11807, doi:10.1029/2008GL033741, 2008.

Slemr, F., Ebinghaus, R., Brenninkmeijer, C. A. M., Hermann, M., Kock, H. H., Martinsson, B. G., Schuck, T., Sprung, D., Velthoven, P., Zahn, A., and Ziereis, H.: Gaseous mercury distribution in the upper troposphere and lower stratosphere observed onboard the CARIBIC passenger aircraft, Atmos. Chem. Phys., 9, 1957-1969, doi:10.5194/acp-9-1957-2009, 2009.

Slemr, F., Brunke, E.-G., Ebinghaus, R., and Kuss, J.: Worldwide trend of atmospheric mercury since 1995, Atmos. Chem. Phys., 11, 4779-4787, doi:10.5194/acp-11-4779-4787, 2011.

Swartzendruber, P. C., Jaffe, D. A., Prestbo, E. M., Weiss-Penzias, P., Selin, N. E., Park, R., Jacob, D. J., Strode, S., and Jaegle, L.: Observations of reactive gaseous mercury in the free troposphere at the Mount Bachelor Observatory, J. Geophys. Res., 111, D24302, doi:10.1029/2006jd007415, 2006.

Valente, R. J., Shea, C., Lynn Humes, K., and Tanner, R. L.: Atmospheric mercury in the Great Smoky Mountains compared to regional and global levels, Atmos. Environ., 41, 1861-1873, 2007.

Wan, Q., Feng, X. B., Julia, L., Zheng, W., Song, X. J., Han, S. J., and $\mathrm{Xu}, \mathrm{H}$.: Atmospheric mercury in Changbai Mountain area, northeastern China - Part 1: The seasonal distribution pattern of total gaseous mercury and its potential sources, Envrion. Res., 109, 201-206, 2009.

Wang, S. F., Jia, Y. F., Wang, S. Y., Wang, X., Wang, H., Zhao, Z. X., and Liu, B. Z.: Total mercury and monomethylmercury in water, sediments, and hydrophytes from the reveres, estuary, and bay along the Bohai Sea coast, northeastern China, Appl. Geochem., 24, 1702-1711, 2009.

Wang, Y. Q., Zhang, X. Y., and Draxler, R. R.: TrajStat: GIS-based software that uses various trajectory statistical analysis methods to identify potential sources from long-term air pollution measurement data, Environ. Model. Soft., 24, 938-939, 2009.

Wilson, S. J., Steenhuisen, F., Pacyna, J. M., and Pacyna, E. G.: Mapping the spatial distribution of global anthropogenic mercury atmospheric emission inventories, Atmos. Environ., 40, 46214632, 2006.

Wu, Y., Wang, S. X., Streets, D. G., Hao, F. M., Chan, M., and Jiang, J. K.: Trends in Anthropogenic Mercury Emissions in China from 1995 to 2003, Environ. Sci. Technol., 40, 5312-5318, 2007. 
Temme, C., Slemr, F., Ebinghaus, R., and Einax, J. W.: Distribution of mercury over the Atlantic Ocean in 1996 and 1999-2001, Atmos. Environ., 37, 1889-1897, 2003.
Zhang, H.: Concentrations of speciated atmospheric mercury a high-altitude background station in the Shangri-La area of Tibetan Plateau, China, Abstract to 10th international conference on Mercury as a global pollutant, Halifax, Canada, 2011. 